\title{
Mercury Contamination: A Growing Threat to Riverine and Urban Communities in the Brazilian Amazon
}

\author{
Heloisa do Nascimento de Moura Meneses ${ }^{1, *}$, Marcelo Oliveira-da-Costa ${ }^{2}$ (D), Paulo Cesar Basta ${ }^{3}$ (D), \\ Cristiano Gonçalves Morais ${ }^{1}$, Romulo Jorge Batista Pereira ${ }^{1}$, Suelen Maria Santos de Souza ${ }^{4}$ and \\ Sandra de Souza Hacon ${ }^{3}$
}

Citation: Meneses, H.d.N.d.M.; Oliveira-da-Costa, M.; Basta, P.C.;

Morais, C.G.; Pereira, R.J.B.;

de Souza, S.M.S.; Hacon, S.d.S.

Mercury Contamination: A Growing Threat to Riverine and Urban Communities in the Brazilian Amazon. Int. J. Environ. Res. Public Health 2022, 19, 2816. https:// doi.org/10.3390/ijerph19052816

Academic Editor: Paul B. Tchounwou

Received: 5 January 2022

Accepted: 24 February 2022

Published: 28 February 2022

Publisher's Note: MDPI stays neutral with regard to jurisdictional claims in published maps and institutional affiliations.

Copyright: (C) 2022 by the authors. Licensee MDPI, Basel, Switzerland. This article is an open access article distributed under the terms and conditions of the Creative Commons Attribution (CC BY) license (https:// creativecommons.org/licenses/by/ $4.0 /)$.
1 Programa de Pós-Graduação em Ciências da Saúde (PPGCSA), Universidade Federal do Oeste do Pará, Rua Vera Paz Av. Vera Paz, s/n, Bairro Salé, $1^{\circ}$ Pavimento, Unidade Tapajós, 68035-110 Santarém, Brazil; cristiano.goncalves.moraes@gmail.com (C.G.M.); romulo.jorge55@gmail.com (R.J.B.P.)

2 WWF-Brasil, CLS 114 Bloco D-35, 70377-540 Brasília, Brazil; marcelo@wwf.org.br

3 Escola Nacional de Saúde Pública Sérgio Arouca, Fundação Oswaldo Cruz, Rua Leopoldo Bulhões, 1480 Manguinhos, 21041-210 Rio de Janeiro, Brazil; paulobasta@gmail.com (P.C.B.); shacon@ensp.fiocruz.br (S.d.S.H.)

4 Programa de Pós-Graduação em Sociedade Natureza e Desenvolvimento (PPGSND), Universidade Federal do Oeste do Pará, Rua Vera Paz Av. Vera Paz, s/n, Bairro Salé, $1^{\circ}$ Pavimento, Unidade Tapajós, 68035-110 Santarém, Brazil; s.s.souza@hotmail.com

* Correspondence: heloisa.meneses@ufopa.edu.br

\begin{abstract}
In recent decades, widespread and uncontrolled use of mercury $(\mathrm{Hg})$ in artisanal small-scale gold mining has released thousands of tons of mercury-contaminated waste in the Amazon biome, endangering the largest tropical rainforest worldwide. In this study, we assessed and compared blood $\mathrm{Hg}$ levels in individuals living in urban and riverine areas in the lower Tapajós basin and examined the association between $\mathrm{Hg}$ exposure and specific biochemical parameters. In total, 462 adults from eight riverine communities and one urban area were assessed. Overall, 75.6\% of the participants exhibited $\mathrm{Hg}$ concentrations exceeding the safe limit $(10 \mu \mathrm{g} / \mathrm{L}) . \mathrm{Hg}$ exposure was higher in the riverine population (90\%) than in urban areas (57.1\%). Mean $\mathrm{Hg}$ levels were $21.8 \pm 30.9 \mu \mathrm{g} / \mathrm{L}$ and $50.6 \mu \mathrm{g} / \mathrm{L}$ in urban and riverine residents, respectively. The mean $\mathrm{Hg}$ level was higher in those aged 41-60 years in both urban and riparian areas, with riparian residents exhibiting a mean double that of urban residents. The highest glucose and hepatic biomarker levels were detected in the urban area, whereas the highest levels of renal biomarker occurred in the riverine population. Our results indicate that $\mathrm{Hg}$ contamination remains a persistent challenge for the urban population of Santarém, a major city in the Brazilian Amazon.
\end{abstract}

Keywords: gold mining; blood sampling; Tapajós basin; biochemical markers; Santarém

\section{Introduction}

Mercury $(\mathrm{Hg})$ is one of the most harmful chemicals on earth and represents a global public health challenge. Although a naturally occurring element, human activities have increased the total atmospheric $\mathrm{Hg}$ concentration by approximately $450 \%$ above natural levels [1]. In Latin America, artisanal small-scale gold mining (ASGM) remains the primary source of $\mathrm{Hg}$ emissions and contamination [2], and along with biomass burning and deforestation, accounts for most of the $\mathrm{Hg}$ released in the Amazon [3].

$\mathrm{Hg}$ has been used to extract gold for centuries and is still a widely employed technique in Southern America because it is an easy and inexpensive process. Over the last four decades, the widespread, unregulated, and uncontrolled use of $\mathrm{Hg}$ in ASGM has released thousands of tons of mercury-contaminated waste in the Amazon biome. In the Brazilian Amazon, ASGM was found to be responsible for environmental contamination, as well as wildlife and human exposure over the years [4]; however, the magnitude of exposure remains unclear owing to the illegality of the sector, hampering credible data on the 
amount of $\mathrm{Hg}$ released in the environment [5]. For individuals living in the Amazon, fish consumption is the main source of exposure [6,7], which endangers the food security and livelihood of traditional communities in the region [8].

$\mathrm{Hg}$ exposure may cause various important health issues, including damage to the neurological, cardiovascular, immunological, and digestive systems, lungs, kidneys, skin, and eyes [9-11]. Organic forms of $\mathrm{Hg}$, such as methylmercury ( $\mathrm{MeHg}$ ), are particularly toxic to humans and are rapidly absorbed by the body, widely distributed in all tissues, and slowly eliminated [3]. Maternal Hg exposure has been associated with a series of developmental effects, and it may cause several chronic lifelong disorders [12,13]. Such heterogeneous toxicity translates into a complex variety of possible clinical manifestations induced by mercury intoxication, complicating clinical diagnostic and epidemiological studies [14,15].

The Tapajós basin is the fifth largest tributary of the Amazon basin, covering approximately $492,000 \mathrm{~km}^{2}$ and plays important social, cultural, and economic roles. However, instead of promoting socially inclusive and environmentally sustainable development in the region, federal administrations have supported controversial activities, including gold mining. This includes the creation of the gold mining zone, Reserva Garimpeira do Tapajós, in 1983, which attracted thousands of people towards the search for gold.

High gold prices in the international market and political instability have boosted illegal gold mining in the Brazilian Amazon. The rate of deforestation due to illegal mining increased by more than $90 \%$ from 2017 to 2020, reaching $101.7 \mathrm{~km}^{2}$ in 2020 [16]. Furthermore, there is a disconnection between the Brazilian health information system and cases of $\mathrm{Hg}$ contamination in the Amazon [17], with a critical deficiency in the information system regarding the data on human $\mathrm{Hg}$ intoxication from the Amazon States. This is of great concern, as it undermines the ability of decision-makers and government agencies to develop strategies and actions to mitigate this issue. Since 1980, several studies assessing human $\mathrm{Hg}$ exposure in the Brazilian Amazon were conducted in the Tapajós basin [4,18-20]. Although these studies reported widespread Hg contamination in the basin, few investigated the urban population. This is probably due to the prioritization of riverine and indigenous populations, which are among the most vulnerable communities in the Amazon, with scarce access to the healthcare system and high dependency on fish as their main protein source.

The objectives of the present study were to (1) evaluate and (2) compare $\mathrm{Hg}$ levels in blood samples from residents of urban and riverine areas in the lower Tapajós basin. Our study also (3) describes the health situation of urban and riverine residents in the lower Tapajós River. We aim to contribute to qualifying the magnitude of $\mathrm{Hg}$ contamination in the Amazon and support the development of national and subnational strategies to manage this issue, as well as present evidence indicating the threat to human well-being in the region.

\section{Methods}

\subsection{Study Design and Population}

A cross-sectional investigation was conducted between 2015 and 2019. Participants from riverine communities and one urban area along the lower Tapajós basin were voluntarily recruited with the support of local community leaders, followed by meetings in the communities. A total of 462 adults (>18 years old) from eight communities (Vila Franca, Maripá, Pedra Branca, Suruacá, Parauá, Surucuá, São Tomé, and Boim) and one community from the Amazon River (Tapará Grande) and the urban area of Santarém (Figure 1) were selected, excluding pregnant women and people living in indigenous communities, mostly because these groups were the main target in previous studies. Sociodemographic data, gender, age, frequency of fish intake, and educational level (years of schooling) were obtained through an interview-administered questionnaire adapted from protocols for environmental and health assessments. Based on questionnaires, no subject of this study had an established record of involvement with ASGM. Questionnaires with inconsistencies in terms of some variables, notably due to recording failures, were discarded. At 
the end of the interview, all participants were weighed and measured, body mass index $\left(\mathrm{BMI}=\right.$ weight $[\mathrm{kg}] /$ height $\left.[\mathrm{m}]^{2}\right)$ was calculated, and blood pressure was monitored. The participants were categorized into illiterate, elementary education (up to 12 years of study), or higher education (over 12 years of study) groups. Fish consumption was classified as follows: daily consumption, regular consumption ( 1 to 3 times a week), and occasional consumption (maximum 2 times a month).

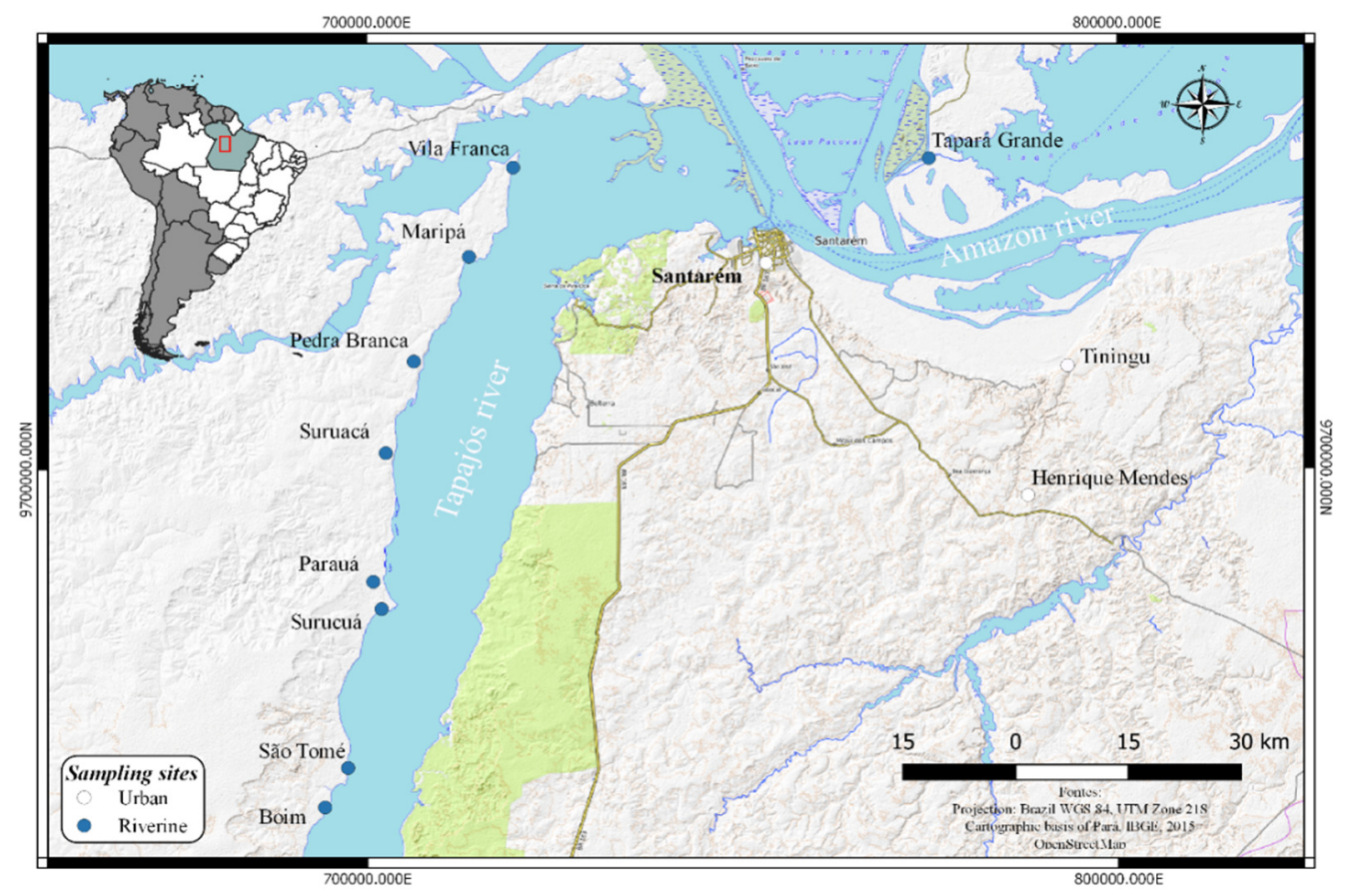

Figure 1. Map of the study area indicating sampling sites.

All procedures were approved by the Ethics Committee of Pará State University (UEPA) (Technical Report No. 1,127,108), and all participants provided written informed consent prior to the interviews.

\subsection{Blood Sampling and Analysis}

We collected $10 \mathrm{~mL}$ of venous blood by venipuncture from each participant, which were then divided into two samples: $5 \mathrm{~mL}$ were added to a tube with EDTA anticoagulant for $\mathrm{Hg}$ analysis, and the remaining $5 \mathrm{~mL}$ were poured into a tube without anticoagulant to measure serum levels of renal and hepatic markers. All tubes were stored in thermal boxes for transportation to the laboratory. Tubes containing anticoagulants were stored in a freezer at a temperature below $0{ }^{\circ} \mathrm{C}$ until dosage. The sample tubes without anticoagulant were centrifuged at $3500 \mathrm{rpm}$ for $5 \mathrm{~min}$, and the clot was discarded using a micropipette, which is crucial because hepatic enzymes in contact with blood cells undergo degradation, which may mask hepatic alterations. The serum amount was measured on the sampling day and the remaining serum was stored in a freezer for replicate measurements, if necessary. Sampling procedures, storage, and transportation were performed in accordance with the guidelines recommended by the Brazilian Society of Clinical Analysis.

Total $\mathrm{Hg}$ concentrations in the blood were analyzed by atomic absorption spectrometry using a direct mercury analyzer (DMA-80; Milestone Inc., Santa Clara, CA, USA). The accuracy of the results was determined using a calibration curve with certified reference materials (CRM) (Seronorm ${ }^{\mathrm{TM}}$ Trace Elements Whole Blood, Billingstad, Norway). The detection limit of the assay was $0.2 \mu \mathrm{g} / \mathrm{L}$, and samples were analyzed in duplicate. $\mathrm{Hg}$ exposure level was defined as low exposure $(\leq 10 \mu \mathrm{g} / \mathrm{L})$ or high exposure $(\geq 10 \mu \mathrm{g} / \mathrm{L})$, following the threshold set for blood $(10 \mu \mathrm{g} / \mathrm{L})$ by the World Health Organization (WHO) [21]. Concentrations of biochemical markers were determined, including glucose (non-fasting), 
urea, and creatinine (for kidney function), alanine aminotransferase (AST), and aspartate aminotransferase (ALT) (for liver function). The analyses were performed using the BS 200 equipment from MINDRAY, according to the manufacturer's instructions. Creatinine and urea values are expressed in milligrams per deciliter $(\mathrm{mg} / \mathrm{dL})$, and AST and ALT results are expressed in units per liter (U/L); the reference values adopted varied according to the participant's age. All biochemical markers were analyzed in a certified laboratory and "LabTest Diagnóstica" kits were used. The CRM varies according to the type of analysis performed, being: Enzymatic Glucose Oxidase-Peroxidase (reference value 133-glucose), Kinetic UV Urease (GLDH) (reference value 104-urea), Enzymatic Colorimetric (reference value 96-creatinine), and Kinetic UV-IFCC Without Pyridixal Phosphate (reference value 109-AST and reference value 108-ALT).

\subsection{Statistical Analysis}

Descriptive statistics (mean, median, standard deviation) were used to examine $\mathrm{Hg}$ levels and biomarker concentrations in relation to the participant's residence location (urban or riverine). The epidemiological profile was evaluated according to $\mathrm{Hg}$ exposure level (low or high) and participants' residence location (urban or riverine) using Pearson's Chi-square test for heterogeneity. In addition to descriptive analyses, potential associations considering $\mathrm{Hg}$ levels and (1) age, (2) gender, (3) schooling, and (4) fish consumption were evaluated using the Shapiro-Wilk test to verify normally distributed data, and the KruskalWallis test was applied as the non-parametric method, and the Spearman's test was used for the age correlation analysis. A health situational diagnosis analysis of the research participants was conducted, detailing the occurrence of altered biochemical parameters, blood pressure, and BMI in urban and riverine residents.

All statistical tests were performed using STATA software version 16, with a significance level of $5 \%$.

\section{Results}

Hg levels were detected in all 203 individuals from Santarém City and 259 participants from riverine communities assessed in the present study. Among the participants, 75.6\% exhibited $\mathrm{Hg}$ levels exceeding the safe limit set by the WHO and were defined as the highexposure group. Mean $\mathrm{Hg}$ levels in the high exposure group were $48.3 \pm 58.5 \mu \mathrm{g} / \mathrm{L}$, whereas the low exposure group showed a level of $6.2 \pm 2.2 \mu \mathrm{g} / \mathrm{L}$. Among the 349 participants in this group, $77.1 \%$ had $\mathrm{Hg}$ levels ranging between 10 and $50 \mu \mathrm{g} / \mathrm{L}, 11.2 \%$ between 51 and $100 \mu \mathrm{g} / \mathrm{L}, 6.9 \%$ between 101 and $200 \mu \mathrm{g} / \mathrm{L}$, and $4.9 \%$ exhibited $\mathrm{Hg}$ levels $>200 \mu \mathrm{g} / \mathrm{L}$. Strikingly, the highest $\mathrm{Hg}$ level $(296.5 \mu \mathrm{g} / \mathrm{mL})$ was detected in a 47 -year-old woman living at a riverine site, almost 30 -fold higher than the safe limit.

The prevalence of $\mathrm{Hg}$ exposure was higher in the riverine population (90\%) than in those living in urban areas $(57,1 \%)$, with statistically significant differences between the two categories $\left(\chi^{2}=63.3 ; p<0.0001\right)$. Mean $\mathrm{Hg}$ levels in urban area residents were $21.8 \pm 30.9 \mu \mathrm{g} / \mathrm{L}$, with levels of $33.6 \mu \mathrm{g} / \mathrm{L} \mathrm{Hg}$ and $5.9 \mu \mathrm{g} / \mathrm{L}$ detected in the high and low exposure groups, respectively. The highest $\mathrm{Hg}$ level in an urban area resident was $247.1 \mu \mathrm{g} / \mathrm{L}$. In the riverine participants, the mean $\mathrm{Hg}$ level was $50.6 \mu \mathrm{g} / \mathrm{L}$, and the high exposure group exhibited a level of $55.5 \mu \mathrm{g} / \mathrm{L} \mathrm{Hg}$; the highest $\mathrm{Hg}$ level noted was $296.5 \mu \mathrm{g} / \mathrm{L}$.

Regarding participants' age, 42.1\% were aged between $41-60$ years old, and 39.5\% were $21-40$ years old. In this older group (41-60), the mean $\mathrm{Hg}$ level was $44.3 \pm 59.3 \mu \mathrm{g} / \mathrm{L}$, whereas the younger group (21-40) showed $\mathrm{Hg}$ levels of $32.1 \pm 49.6 \mu \mathrm{g} / \mathrm{L}$ (Table 1). Considering gender, $65.6 \%$ were female with a mean $\mathrm{Hg}$ level of $32.7 \pm 47.3 \mu \mathrm{g} / \mathrm{L},($ minimum $=1.4 \mu \mathrm{g} / \mathrm{L}$ and maximum $=296.5 \mu \mathrm{g} / \mathrm{L}$ ), and 34.4\% were males displaying a mean $\mathrm{Hg}$ level of $48.1 \pm 63.9 \mu \mathrm{g} / \mathrm{L}$ $($ minimum $=1.7 \mu \mathrm{g} / \mathrm{L}$ and maximum $=288.3 \mu \mathrm{g} / \mathrm{L})$. In terms of schooling, $73.1 \%$ of participants were in the elementary education category; however, the highest level of $\mathrm{Hg}$ was detected in the illiterate group $(45.8 \pm 50.9 \mu \mathrm{g} / \mathrm{L})$, while $24.3 \%$ of participants (higher education category) showed the lowest $\mathrm{Hg}$ level $(17.3 \pm 31.6 \mu \mathrm{g} / \mathrm{L})$. Regarding fish consumption, most participants 
( $n=235$ ) reported regular consumption. Unsurprisingly, the group with daily fish consumption habits showed the highest $\mathrm{Hg}$ level $(48.1 \pm 59.9 \mu \mathrm{g} / \mathrm{L})$.

Table 1. Epidemiological characteristics of participants according to $\mathrm{Hg}$ levels, Brazilian Amazon basin, 2015-2019.

\begin{tabular}{|c|c|c|c|c|c|c|c|c|c|c|}
\hline \multirow[b]{2}{*}{ Variables } & \multicolumn{2}{|c|}{ Low Exposure } & \multicolumn{2}{|c|}{ High Exposure } & \multicolumn{5}{|c|}{ Total Hg Level in the Blood $(\mu \mathrm{g} / \mathrm{L})$} & \multirow[b]{2}{*}{$\begin{array}{l}\text { Kruskal- } \\
\text { Wallis }\end{array}$} \\
\hline & $n$ & $\%$ & $n$ & $\%$ & Mean & Median & $\begin{array}{l}\text { Standard } \\
\text { Deviation }\end{array}$ & Min & $\operatorname{Max}$ & \\
\hline \multicolumn{11}{|c|}{ Age range $(n=451) *$} \\
\hline $18-20(n=21)$ & 10 & 47.6 & 11 & 52.4 & 20.9 & 12.0 & 27.6 & 3.7 & 129.6 & \\
\hline $21-40(n=178)$ & 54 & 30.3 & 124 & 69.7 & 32.1 & 15.0 & 49.6 & 1.4 & 288.3 & $x^{2}=19.05$ \\
\hline $41-60(n=190)$ & 37 & 19.5 & 153 & 80.5 & 44.3 & 23.5 & 59.3 & 1.6 & 296.5 & $p=0.0003$ \\
\hline$>61(n=62)$ & 10 & 16.1 & 52 & 83.9 & 39.7 & 22.1 & 49.6 & 3.3 & 271.9 & \\
\hline \multicolumn{11}{|c|}{ Gender $(n=462)$} \\
\hline Female $(n=303)$ & 80 & 26.4 & 223 & 73.6 & 32.7 & 16.8 & 47.3 & 1.4 & 296.5 & $x^{2}=9.11$ \\
\hline Male $(n=159)$ & 33 & 20.8 & 126 & 79.2 & 48.1 & 25.5 & 63.9 & 1.7 & 288.3 & $p=0.003$ \\
\hline \multicolumn{11}{|c|}{ Schooling $(n=457) *$} \\
\hline Illiterate $(n=12)$ & 3 & 25.0 & 9 & 75.0 & 45.8 & 30.7 & 50.9 & 7.3 & 185.5 & \\
\hline Elementary education $(n=334)$ & 52 & 15.6 & 282 & 84.4 & 44.7 & 24.0 & 58.5 & 1.4 & 296.5 & $\chi^{2}=67.85$ \\
\hline Higher education $(n=111)$ & 57 & 51.4 & 54 & 48.6 & 17.3 & 9.6 & 31.6 & 1.6 & 296.5 & \\
\hline \multicolumn{11}{|c|}{ Fish consumption $(n=457) *$} \\
\hline Daily $(n=146)$ & 5 & 3.4 & 141 & 96.6 & 48.1 & 26.1 & 59.9 & 7.0 & 296.5 & \\
\hline Regular $(n=235)$ & 57 & 24.3 & 178 & 75.7 & 40.7 & 20.1 & 56.1 & 1.4 & 296.5 & $\chi^{2}=88.62$ \\
\hline Occasional $(n=76)$ & 47 & 61.8 & 29 & 38.2 & 12.1 & 7.6 & 14.2 & 1.6 & 80.1 & $p=0.0001$ \\
\hline \multicolumn{11}{|c|}{ Home location $(n=462) *$} \\
\hline Riverine-Amazon River $(n=105)$ & 16 & 15.2 & 89 & 84.7 & 45.3 & 27.3 & 55.2 & 3.3 & 271.9 & \\
\hline Riverine-Tapajós River $(n=154)$ & 10 & 6.5 & 144 & 93.5 & 54.3 & 25.0 & 69.3 & 1.4 & 296.5 & $\chi^{2}=79.21$ \\
\hline Urban $(n=203)$ & 87 & 42.9 & 116 & 57.1 & 21.8 & 11.0 & 30.9 & 1.7 & 247.1 & \\
\hline
\end{tabular}

${ }^{*} \chi^{2}$ of person: Comparison of variables such as age, schooling, fish consumption, and location of residence as a function of mercury exposure (high exposure $\times$ low exposure) shows statistically significant results.

The prevalence of $\mathrm{Hg}$ exposure in the riverine participants along the Tapajós River (59.5\%) was higher than that along the Amazon River (40.5\%).

The profile was also described in relation to the participant's location of residence (Table 2). In the urban area, the mean $\mathrm{Hg}$ level was $33.6 \pm 36.7 \mu \mathrm{g} / \mathrm{L}$, while a level of $55.5 \pm 65.7 \mu \mathrm{g} / \mathrm{L}$ was recorded in the riverine area. The prevalence of high exposure was greater among riverine residents $(\mathrm{PR}=1.57,95 \%$ confidence interval $[\mathrm{CI}]=1.38-1.78$, $p=0.000$ ), with a statistically significant difference when comparing median $\mathrm{Hg}$ levels among the two residence locations $\left(\chi^{2}=78.684, p=0.0001\right)$. Moreover, differences were observed when comparing urban and riverine areas of the Amazon River $\left(\chi^{2}=6.46\right.$, $p<0.0001)$ and between urban and riverine areas of the Tapajós River $\left(\chi^{2}=8.13, p<0.0001\right)$, but not between participants in the two riverine areas $\left(\chi^{2}=-0.72, p=0.7009\right)$.

The mean $\mathrm{Hg}$ level was higher in participants aged 41 to 60 years in both urban and riparian areas $(28.7 \pm 37.3 \mu \mathrm{g} / \mathrm{L}$ and $55.6 \pm 68.8 \mu \mathrm{g} / \mathrm{L}$, respectively), with the riparian area recording a mean nearly two-fold that of the urban area. A statistically significant difference was observed among all age groups when comparing urban and riparian areas.

Although both areas showed a higher number of females $(64 \%$ in the riverine and $67 \%$ in the urban area) at a higher exposure risk, $\mathrm{Hg}$ levels were higher among males in both riverine and urban areas $(63.4 \pm 70.7 \mu \mathrm{g} / \mathrm{L}$ and $26.5 \pm 46.0 \mu \mathrm{g} / \mathrm{L}$ respectively). For both sexes, a higher $\mathrm{Hg}$ level was observed in the riverine area than that in the urban area $\left(\chi^{2}=36.05 ; p=0.0001\right.$ female; $\chi^{2}=44.02 ; p=0.0001$ male $)$.

Regarding schooling, most participants of both locations were categorized into elementary education group, but of 111 individuals in the higher education category, 89 were from the urban area exhibiting the lowest mean $\mathrm{Hg}$ level $(12.2 \pm 12.8 \mu \mathrm{g} / \mathrm{L})$. In riverine areas, participants from both elementary and higher education groups showed higher levels of $\mathrm{Hg}\left(\chi^{2}=28.16 ; p=0.0001\right.$ and $\chi^{2}=15.08 ; p=0.0001$, respectively $)$. 
Regarding the frequency of fish consumption, the categories "daily" and "regular" were, as expected, the most reported in urban and riverine areas. We detected a statistically significant difference between urban and riparian areas in all fish consumption categories.

Table 2. Epidemiological profiling of participants according to residence location, Brazilian Amazon basin, 2015-2019.

\begin{tabular}{|c|c|c|c|c|c|c|c|c|c|}
\hline \multirow[b]{2}{*}{ Variables } & \multirow{2}{*}{$\begin{array}{l}\text { Residence } \\
\text { Location }\end{array}$} & \multirow[b]{2}{*}{$n$} & \multirow[b]{2}{*}{$\%$} & \multicolumn{5}{|c|}{ Total Hg Level in the Blood $(\mu \mathrm{g} / \mathrm{L})$} & \multirow[b]{2}{*}{$\begin{array}{c}\text { Kruskal } \\
\text { Wallis }\end{array}$} \\
\hline & & & & Mean & Median & $\begin{array}{c}\text { Standard } \\
\text { Deviation }\end{array}$ & Min & Max & \\
\hline \multicolumn{10}{|c|}{ Age range } \\
\hline \multirow{2}{*}{$18-20(n=21) *$} & Riverine & 12 & 57.1 & 30.4 & 19.9 & 33.6 & 6.9 & 129.6 & $x^{2}=9.78$ \\
\hline & Urban & 9 & 42.9 & 8.2 & 6.6 & 6.1 & 3.7 & 23.8 & $p=0.0019$ \\
\hline \multirow{2}{*}{$21-40(n=178) *$} & Riverine & 98 & 55.1 & 45.7 & 25.0 & 58.7 & 1.4 & 288.3 & $\chi^{2}=59.19$ \\
\hline & Urban & 80 & 44.9 & 15.4 & 8.5 & 27.9 & 2.3 & 222.7 & $p=0.0001$ \\
\hline \multirow{2}{*}{$41-60(n=191) *$} & Riverine & 112 & 58.6 & 55.6 & 28.6 & 68.8 & 1.6 & 296.5 & $x^{2}=15.92$ \\
\hline & Urban & 79 & 41.4 & 28.7 & 14.9 & 37.3 & 1.7 & 247.1 & $\hat{p}=0.0001$ \\
\hline \multirow{2}{*}{$>61(n=62) *$} & Riverine & 31 & 50.0 & 53.8 & 27.0 & 64.9 & 5.8 & 271.9 & $x^{2}=5.13$ \\
\hline & Urban & 31 & 50.0 & 24.7 & 17.5 & 21.1 & 3.3 & 80.1 & $p=0.0235$ \\
\hline \multicolumn{10}{|c|}{ Gender } \\
\hline \multirow{4}{*}{ Female $(n=303) *$} & Riverine & 166 & 54.8 & 43.6 & 21.6 & 59.1 & 1.4 & 296.5 & $x^{2}=36.05$ \\
\hline & Urban & 137 & 45.2 & 19.5 & 10.1 & 20.0 & 2.3 & 102.4 & $p=0.0001$ \\
\hline & Riverine & 93 & 58.5 & 63.3 & 35.0 & 70.4 & 3.3 & 288.3 & $x^{2}=44.02$ \\
\hline & Urban & 66 & 41.5 & 26.5 & 11.2 & 46.0 & 1.7 & 247.1 & $p=0.0001$ \\
\hline \multicolumn{10}{|c|}{ Schooling } \\
\hline \multirow{2}{*}{ Illiterate $(n=12)$} & Riverine & 7 & 58.4 & 50.9 & 14.8 & 66.8 & 7.3 & 185.5 & $x^{2}=0.53$ \\
\hline & Urban & 5 & 41.7 & 38.6 & 34.8 & 18.1 & 21.1 & 67.3 & $p=0.4649$ \\
\hline \multirow{2}{*}{ Elementary education $(n=334)$ * } & Riverine & 226 & 67.7 & 52.2 & 27.3 & 64.5 & 1.4 & 296.5 & $\chi^{2}=28.16$ \\
\hline & Urban & 108 & 32.4 & 28.9 & 15.4 & 39.0 & 1.7 & 247.1 & $\begin{array}{l}X=20.10 \\
p=0.0001\end{array}$ \\
\hline \multirow{2}{*}{ Higher education $(n=111) *$} & Riverine & 22 & 19.8 & 37.8 & 18.5 & 63.2 & 1.6 & 296.5 & $\chi^{2}=15.08$ \\
\hline & Urban & 89 & 80.2 & 12.2 & 8.7 & 12.8 & 2.3 & 82.8 & $p=0.0001$ \\
\hline \multicolumn{10}{|c|}{ Fish consumption } \\
\hline \multirow{2}{*}{ Daily $(n=146) *$} & Riverine & 128 & 87.7 & 50.0 & 27.3 & 60.6 & 6.7 & 296.5 & $x^{2}=3.731$ \\
\hline & Urban & 18 & 12.3 & 34.8 & 21.6 & 54.6 & 8.4 & 247.1 & $p=0.0534$ \\
\hline \multirow{2}{*}{ Regular $(n=235) *$} & Riverine & 123 & 47.7 & 52.9 & 25.4 & 68.9 & 1.4 & 296.5 & $x^{2}=14.03$ \\
\hline & Urban & 112 & 52.3 & 27.2 & 14.6 & 32.5 & 1.7 & 222.7 & $p=0.0002$ \\
\hline \multirow{2}{*}{ Occasional $(n=76) *$} & Riverine & 7 & 9.2 & 28.6 & 16.6 & 24.3 & 1.6 & 74.9 & $\chi^{2}=6.831$ \\
\hline & Urban & 69 & 90.8 & 10.4 & 6.7 & 11.8 & 2.4 & 80.1 & $\begin{array}{l}x=0.0091 \\
p=0.0090\end{array}$ \\
\hline
\end{tabular}

${ }^{*}$ Kruskal-Wallis: Comparison of residence location (urban $\times$ riverside) showed a statistically significant result.

For the total samples (with no epidemiological categories), we evaluated four potential associations: (1) $\mathrm{Hg}$ level and age, demonstrating a positive and statistically significant correlation $\left(\mathrm{r}_{\mathrm{s}}=0.23 ; p<0.0001\right)$. A similar correlation was observed for the urban area $\left(r_{s}=0.37 ; p<0.0001\right)$, whereas in riverine areas, this correlation was not statistically significant $\left(\mathrm{r}_{\mathrm{s}}=0.12 ; p=0.06\right)$. (2) $\mathrm{Hg}$ level and sex: men had higher $\mathrm{Hg}$ levels than women $\left(\chi^{2}=9.10, p=0.0025\right)$. In females, a positive and statistically significant correlation was detected between age and $\mathrm{Hg}$ levels $\left(\mathrm{r}_{\mathrm{s}}=0.26 ; p<0.0001\right)$, but no significant correlation was observed between age and $\mathrm{Hg}$ levels in male participants $\left(\mathrm{r}_{\mathrm{s}}=0.11 ; p=0.16\right)$. (3) The $\mathrm{Hg}$ level and schooling resulted in a statistically significant difference $\left(\chi^{2}=67.84, p=0.0001\right)$, with a statistically significant difference between elementary and higher education (8.15, $p<0.0001)$, as well as between illiterate and higher education $\left(\chi^{2}=3.31, p=0.0014\right)$. (4) The $\mathrm{Hg}$ level and fish consumption were significantly different $\left(\chi^{2}=88.62, p=0.0001\right)$, with a higher difference between daily and occasional fish consumption $\left(\chi^{2}=9.37, p<0.0001\right)$.

The situational health diagnosis conducted in all participants showed that the median biomarker levels were within the reference range. The highest glucose and hepatic biomarker levels were documented in urban area residents; the highest levels of renal biomarkers were noted in participants living in the riverine area (Table 3).

Regarding renal markers, it was observed that 19 residents presented altered levels of urea, of which $16(84.2 \%)$ were from the riverine area, $3(15.8 \%)$ from the urban area, and 6 residents presented altered levels of creatinine, of which $5(83.3 \%)$ were from the riverine area (Table 4$)$. The highest levels of urea $(115.7 \mathrm{mg} / \mathrm{dL})$ and creatinine $(4.4 \mathrm{mg} / \mathrm{dL})$ 
were observed in the same participant, a 65-year-old woman from the riverine area, who presented a Hg level of $122.8 \mu \mathrm{g} / \mathrm{L}$.

Table 3. Descriptive analyses of the biochemical marker concentrations in participants' blood samples, according to residence location (riverine vs. urban), Brazilian Amazon basin, 2015-2019.

\begin{tabular}{|c|c|c|c|c|c|c|c|c|}
\hline \multirow{2}{*}{$\begin{array}{l}\text { Biochemical } \\
\text { Markers }\end{array}$} & \multirow{2}{*}{ Reference Values } & \multirow{2}{*}{$\begin{array}{l}\text { Residence } \\
\text { Location }\end{array}$} & \multirow[t]{2}{*}{$n$} & \multicolumn{5}{|c|}{ Blood levels } \\
\hline & & & & Mean & Median & Standard Deviation & Min & $\operatorname{Max}$ \\
\hline \multirow{2}{*}{ Glucose (mg/dL) } & \multirow{2}{*}{$\begin{array}{c}<160 \text { normal } \\
>160 \text { abnormal }\end{array}$} & Riverine & 102 & 122.9 & 116.0 & 37.9 & 67.0 & 339.0 \\
\hline & & Urban & 123 & 118.7 & 104.0 & 54.3 & 62.0 & 429.0 \\
\hline \multirow[b]{2}{*}{ Urea (mg/dL) } & \multirow[b]{2}{*}{ 10-45 women/men } & Riverine & 100 & 34.5 & 32.2 & 15.3 & 13.9 & 115.7 \\
\hline & & Urban & 131 & 28.3 & 28.0 & 8.7 & 10.0 & 77.0 \\
\hline \multirow{2}{*}{ Creatinine (mg/dL) } & 0.51-1.10-women & Riverine & 100 & 0.9 & 0.9 & 0.4 & 0.2 & 4.4 \\
\hline & $0.7-1.20-$ men & Urban & 131 & 0.9 & 0.8 & 0.3 & 0.3 & 2.3 \\
\hline \multirow{2}{*}{ AST (U/L) } & 10-37-women & Riverine & 100 & 23.0 & 23.0 & 9.9 & 3.0 & 59.0 \\
\hline & 11-39-men & Urban & 131 & 33.6 & 31.0 & 22.1 & 12.0 & 232.0 \\
\hline \multirow{2}{*}{$\operatorname{ALT}(\mathrm{U} / \mathrm{L})$} & 10-47-women & Riverine & 100 & 19.8 & 18.0 & 12.0 & 2.0 & 53.0 \\
\hline & $11-45-$ men & Urban & 131 & 29.1 & 24.0 & 20.6 & 11.0 & 143.0 \\
\hline
\end{tabular}

AST, alanine aminotransferase; ALT, aspartate aminotransferase.

Table 4. Descriptive analyses of the health indicators, according to residence location (riverine vs. urban), Brazilian Amazon basin, 2015-2019.

\begin{tabular}{|c|c|c|c|c|c|c|}
\hline \multirow{2}{*}{\multicolumn{2}{|c|}{ Health Indicators }} & \multicolumn{2}{|c|}{ Urban Area } & \multicolumn{2}{|c|}{ Riverine Area } & \multirow[t]{2}{*}{ Total } \\
\hline & & $n$ & $\%$ & $n$ & $\%$ & \\
\hline \multirow{2}{*}{ Glucose $(n=225)$} & Normal & 108 & 54.0 & 92 & 46.0 & 200 \\
\hline & Abnormal & 15 & 60.0 & 10 & 40.0 & 25 \\
\hline \multirow{2}{*}{ Urea } & Normal & 128 & 60.4 & 84 & 39.6 & 212 \\
\hline & Abnormal & 3 & 15.8 & 16 & 84.2 & 19 \\
\hline \multirow{2}{*}{ Creatinine } & Normal & 130 & 57.8 & 95 & 42.2 & 225 \\
\hline & Abnormal & 1 & 16.7 & 5 & 83.3 & 6 \\
\hline \multirow{2}{*}{ AST } & Normal & 109 & 52.9 & 97 & 47.1 & 206 \\
\hline & Abnormal & 22 & 88.0 & 3 & 12.0 & 25 \\
\hline \multirow{2}{*}{ ALT } & Normal & 114 & 53.5 & 99 & 46.5 & 213 \\
\hline & Abnormal & 17 & 94.4 & 1 & 5.6 & 18 \\
\hline \multirow{2}{*}{ Blood pressure } & Normal & 103 & 39.5 & 158 & 60.5 & 261 \\
\hline & Abnormal & 22 & 52.4 & 20 & 47.6 & 42 \\
\hline \multirow{4}{*}{ BMI } & Underweight & 3 & 25.0 & 9 & 75.0 & 12 \\
\hline & Normal weight & 33 & 26.0 & 94 & 74.0 & 127 \\
\hline & Overweight & 39 & 42.4 & 53 & 57.6 & 92 \\
\hline & Obese & 50 & 65.8 & 26 & 34.2 & 76 \\
\hline
\end{tabular}

For liver markers, 25 participants ( $88.0 \%$ from urban area) presented AST levels above the reference value, while 18 participants $(94.4 \%$ from urban area) showed altered TGP levels. A 44-year-old woman $(\mathrm{Hg}$ level $=50.2 \mu \mathrm{g} / \mathrm{L})$ and a 53-year-old woman $(\mathrm{Hg}$ level $=42.4 \mu \mathrm{g} / \mathrm{L})$, both from urban area, presented elevated levels of AST and ALT: 101.0 U/L of AST and 143.0 U/L of ALT and 232.0 U/L of AST and 120.0 U/L of ALT, respectively.

Glucose, BMI, and blood pressure levels were measured in 191 participants: 98 from the riverine area and 93 from the urban area. 24 of the participants $(12.6 \%)$ had altered glucose levels, of which 15 (62.5\%) had $\mathrm{Hg}$ levels above $10 \mu \mathrm{g} / \mathrm{L}$. Blood pressure was altered in 28 patients $(14.7 \%)$, of which $23(82.1 \%)$ were exposed to elevated levels of $\mathrm{Hg}$. In relation to BMI, 113 participants presented altered weight, of which 63 were overweight and 50 had some degree of obesity, of which 90 (79.6\%) presented Hg levels above the mercury threshold. 


\section{Discussion}

Few studies have addressed Hg exposure in individuals living in urban areas of the Amazon. Most research projects have focused on riverine [22] and indigenous people [7]. Our findings indicate that $\mathrm{Hg}$ contamination remains a threat to riverine communities and impacts the urban population in the Tapajós basin. In addition, all participants included in the present study had high Hg levels; more than three-fourths of the participants exhibited levels exceeding the safety limit set by the WHO, representing a chronic public health issue in the Tapajós region as advocated in previous studies [18,22-25].

Our study differs from other studies performed in the Tapajós Basin, with respect to mainly evaluating residents of the urban area of Santarém and riverside communities that have not been studied yet, as well as a community from the Amazon River. Previous studies were conducted mainly in the Middle Tapajós region, whereas ours was conducted in the Lower Tapajós. To our knowledge, four studies have targeted the population of Santarém, but using different biomarkers of exposure, and consequently undermining correlation between results: (1) in 1995, hair samples from 10 individuals were evaluated and the authors found a mean $\mathrm{Hg}$ level of $2.7 \mu \mathrm{g} / \mathrm{g}$ [26]; (2) in 2000, urine from 50 urban workers were sampled and the mean $\mathrm{Hg}$ level found was $57.5 \mu \mathrm{g} / \mathrm{L}$ [27]; (3) in 2003, hair samples from 44 individuals were evaluated and the average $\mathrm{Hg}$ level found was $3.1 \mu \mathrm{g} / \mathrm{g}$ among residents of the Mapiri neighborhood and $0.8 \mu \mathrm{g} / \mathrm{g}$ among university students [28]; and (4) in 2010, hair samples from 70 individuals were evaluated, resulting in an average $\mathrm{Hg}$ level of $1.5 \mu \mathrm{g} / \mathrm{g}$ in women and $2.52 \mu \mathrm{g} / \mathrm{g}$ in men [29].

The high exposure group presented rates nearly 4-fold higher than the safety limit, reaching almost 30-fold in one analyzed participant. Although the urban population has also been exposed, riverine populations remain the most vulnerable to Hg exposure, presenting a higher proportion of $\mathrm{Hg}$ contamination. This can be explained by evaluating dietary habits [8], as fish remains the predominant protein consumed by riverine populations, while individuals living in cities have access to a greater variety of food [30]. Accordingly, accumulated evidence could trigger additional alerts related to food security. Among these fish-dependent populations, the prevalence of $\mathrm{Hg}$ exposure was higher in the riverine population (90\%) than in those living in urban areas (57.1\%), thus complicating the proposition of mitigating measures.

Along with the regional dietary patterns, the $\mathrm{Hg}$ bioaccumulation feature may also explain the higher Hg levels found in older males. The 40-60-year-old group exhibited relatively higher $\mathrm{Hg}$ levels than the 21-40-year-old participants, with males presenting higher levels than females. As Hg contamination is biocumulative [31] and males usually consume larger meals, it is reasonable to assume that over the years, frequent or daily fish consumption by males, particularly among fishermen families [32], may have led to greater $\mathrm{Hg}$ levels in older males.

Among the total sampled females, $64.7 \%$ were of childbearing age (18 to 49 years), and of these, $69.9 \%$ had mean $\mathrm{Hg}$ levels of $36.2 \mu \mathrm{g} / \mathrm{L}$. This raises serious concerns, given the higher risk of congenital malformations in newborns whose mothers were exposed to $\mathrm{Hg}$ during pregnancy $[33,34]$. $\mathrm{MeHg}$ reportedly crosses the placental and blood-brain barriers and causes more damage to the developing central nervous system than the adult central nervous system. According to Bertossi et al. [35], small amounts of MeHg are sufficient to induce developmental problems in the fetus. Therefore, it is of paramount importance to monitor $\mathrm{Hg}$ levels in women of childbearing age, pregnant women, and their newborns to prevent the effects of mercurial exposure on infants.

Notably, $\mathrm{Hg}$ compounds in the blood reflect recent and current exposure [36]. Accordingly, considering that sampling occurred between 2015 and 2019, it might be reasonable to assume that our results fail to reflect the current scenario in the Tapajós basin, which has reportedly worsened over the last two years, according to several researchers and press. Given the explosion of new gold mining sites in the Munduruku Indigenous territory and other protected areas in the Tapajós basin over the past two years [37], there has been an increase in the indiscriminate use of $\mathrm{Hg}$ upstream of the study area. Furthermore, the 
economic and social crisis triggered by the coronavirus (COVID-19) pandemic has pushed local communities to look for cheaper sources of animal protein. As part of the culture of riverbank populations, fishing efforts have increased, as have the consumption of fish with elevated levels of $\mathrm{Hg}$ [38].

Moreover, in a hypothetical scenario, it is critical to estimate the extent of the issue if the data obtained from this study were extrapolated to the urban population of Santarém, approximately 200,000 inhabitants, which would result in nearly 114,000 people at risk of high levels of $\mathrm{Hg}$ contamination. This absolute number must be questioned, as it depends on important variables such as diet, sex, sample representativeness, frequency of fish consumption, age, exposure to other sources of $\mathrm{Hg}$, such as atmospheric contamination, either by burning emissions or Hg burning $[39,40]$ in gold processing centers, along with other confounding variables. However, even if the total number is overestimated, it is reasonable to assume that human health effects following $\mathrm{Hg}$ contamination, such as mental health impairments [41], as well as behavioral, immunological, hormonal, and reproductive changes [42], among others, can be a reality in the region, representing additional expenses for the local public healthcare system. Alternatively, considering the limited healthcare in the region, this might result in an immeasurable loss in the quality of life for thousands of people.

Although $\mathrm{Hg}$ is a toxic heavy metal associated with tissue damage and can cause different diseases, few studies have examined the effects of $\mathrm{Hg}$ exposure on liver and kidney functions [43]. The health situational analysis showed that both urban and riverside area residents presented alterations in the evaluated health indicators. Alterations in kidney markers were more frequent in riverine residents, and alterations in liver markers were more frequent in urban area residents. Although these are not the most frequently used markers for making an association between $\mathrm{Hg}$ and kidney or liver damage, it is notable that the highest levels of these markers were recorded in people with high $\mathrm{Hg}$ levels.

Regarding blood pressure, participants with hypertension in both urban and riverine areas were observed. Hu et al. [44] conducted a systematic review and meta-analysis to clarify the association between hair $\mathrm{Hg}$ levels and hypertension. On reviewing 29 studies, the authors revealed that the pooled OR for hypertension, comparing the highest and lowest $\mathrm{Hg}$ exposure categories, was 1.35 (95\% CI: 0.99, 1.83) for populations with hair $\mathrm{Hg} \geq 2 \mu \mathrm{g} / \mathrm{g}$ compared with the OR of 1.12 (95\% CI: 0.82, 1.52) for populations with hair $\mathrm{Hg}<2 \mu \mathrm{g} / \mathrm{g}$. These findings suggest a significant positive association between hair $\mathrm{Hg}$ levels and hypertension. Considering that $85.7 \%$ of people with hypertension also presented high levels of mercury, it is reasonable to consider an association between high levels of $\mathrm{Hg}$ and hypertension in the population studied.

Despite these findings, some limitations must be considered. First, the campaigns for data collection occurred during an extended time-lapse, covering 2015 to 2019, making comparisons susceptible to information bias. Another limitation is related to the possibility of comparing results, as most studies in the Amazon have examined urine [45] or hair [22] to study biomarkers of $\mathrm{Hg}$ exposure. In addition, the representativeness of the overall population could be impaired by the voluntary recruitment of participants. Finally, a broad investigation to clarify dietary differences between riverside and urban communities is needed, as there are relevant differences between fish consumption in urban and rural communities and between Brazilian geographic regions [6]. In summary, our findings should be interpreted with caution and considered exploratory.

\section{Conclusions}

People living in communities in the Amazon have been exposed to $\mathrm{Hg}$ for decades through the ingestion of mercury-contaminated fish. Using a biomarker of recent exposure, our results show that $\mathrm{Hg}$ levels are high among the participants. All the individuals analyzed, both from urban and riverine areas, who reported frequent consume of local fish, had detected $\mathrm{Hg}$ levels and were consequently exposed to negative health effects. High levels of this metal were found in people of all age groups, both genders, and all levels of 
education. However, the highest levels were registered in people who reported high daily fish consumption. This indicates that mercury exposure is not only linked to the residence location, but directly influenced by contaminated fish consumption.

To our knowledge, Santarém is far from any goldmining sites. Nevertheless, the local people assessed are exposed to different levels of $\mathrm{Hg}$. Thus, we conclude that exposure to mercury is not restricted to the goldmining site areas but can occur throughout much of the river basin that is greatly impacted by the goldmining activity. We advocate the development of more comprehensive studies to identify mercury contamination from sources other than fish, such as atmospheric and deforestation $\mathrm{Hg}$ emissions.

It is critical to assess the impacts of $\mathrm{Hg}$ contamination on local communities and their environment and build scientific evidence that helps to develop effective mitigation measures and policies. Therefore, tackling the health, environmental and social impacts from $\mathrm{Hg}$ contamination in the region should be among the main goals for governments and decision-makers. Health surveillance programs tailored in accordance with the social and environmental heterogeneity in the Amazon could be the turning point in this issue, claimed for decades as a dangerous threat to the human population.

Author Contributions: Conceptualization, H.d.N.d.M.M.; fieldwork, H.d.N.d.M.M., C.G.M., R.J.B.P., S.M.S.d.S. and S.d.S.H.; data analysis and methodology, H.d.N.d.M.M., S.d.S.H. and P.C.B.; writingoriginal draft preparation, H.d.N.d.M.M., M.O.-d.-C., S.d.S.H. and P.C.B.; writing-review and editing, M.O.-d.-C., P.C.B. and S.d.S.H. All authors have read and agreed to the published version of the manuscript.

Funding: This research was funded by FAPESPA (Project no. 170/2014) and UFOPA, with support from Laboratório Santos for clinical analyses, Laboratório de Bioprospecção e Biologia Experimental (LabBBEx/UFOPA) for mercury analyses, The Nature Conservance Brasil for statistical analyses, and WWF for the preparation and publication of the study.

Institutional Review Board Statement: All procedures were approved by the Ethics Committee of Pará State University (UEPA) (Technical Report No. 1,127,108).

Informed Consent Statement: All participants provided written informed consent prior to the interviews.

Data Availability Statement: https:/ /repositorio.ufopa.edu.br/jspui/handle/123456789/481, accessed on 4 January 2022.

Acknowledgments: We would like to thank all students who participated in this work and CAPES, CNPq, FAPESPA, and UFOPA for their scholarships. We would also like to thank Cassiano Júnior Saatkamp, Geraldo Almeida Neto, and Ricardo Bezerra for their technical support, and the reviewers for their useful comments and suggestions.

Conflicts of Interest: The authors declare no conflict of interest.

\section{References}

1. UNEP. Global Mercury Assessment 2018. In Environment; UN Environment Programme, Chemicals and Health Branch: Geneva, Switzerland, 2019; ISBN 978-92-807-3744-8.

2. UNEP. The Minamata Convention on Mercury and Its Implementation in the Latin America and Caribbean Region [Report; p. 2014]. Pdf. Available online: https:/ / wedocs.unep.org/20.500.11822/32755 (accessed on 25 February 2022).

3. Crespo-Lopez, M.E.; Augusto-Oliveira, M.; Lopes-Araújo, A.; Santos-Sacramento, L.; Yuki Takeda, P.; Macchi, B.M.; do Nascimento, J.L.M.; Maia, C.S.F.; Lima, R.R.; Arrifano, G.P. Mercury: What Can We Learn from the Amazon? Environ. Int. 2021, 146, 106223. [CrossRef] [PubMed]

4. Akagi, H.; Naganuma, A. Human Exposure to Mercury and the Accumulation of Methylmercury That Is Associated with Gold Mining in the Amazon Basin, Brazil. J. Health Sci. 2000, 46, 323-328. [CrossRef]

5. Steckling, N.; Tobollik, M.; Plass, D.; Hornberg, C.; Ericson, B.; Fuller, R.; Bose-O'Reilly, S. Global Burden of Disease of Mercury Used in Artisanal Small-Scale Gold Mining. Ann. Glob. Health 2017, 83, 234-247. [CrossRef]

6. Custódio, F.B.; Andrade, A.M.G.F.; Guidi, L.R.; Leal, C.A.G.; Gloria, M.B.A. Total Mercury in Commercial Fishes and Estimation of Brazilian Dietary Exposure to Methylmercury. J. Trace Elem. Med. Biol. 2020, 62, 126641. [CrossRef]

7. Basta, P.C.; Viana, P.V.S.; Vasconcellos, A.C.S.D.; Périssé, A.R.S.; Hofer, C.B.; Paiva, N.S.; Kempton, J.W.; Ciampi de Andrade, D.; Oliveira, R.A.A.; Achatz, R.W.; et al. Mercury Exposure in Munduruku Indigenous Communities from Brazilian Amazon: 
Methodological Background and an Overview of the Principal Results. Int. J. Environ. Res. Public Health 2021, 18, 9222. [CrossRef] [PubMed]

8. Hacon, S.S.; Oliveira-da-Costa, M.; Gama, C.S.; Ferreira, R.; Basta, P.C.; Schramm, A.; Yokota, D. Mercury Exposure through Fish Consumption in Traditional Communities in the Brazilian Northern Amazon. Int. J. Environ. Res. Public Health 2020, $17,5269$. [CrossRef]

9. Clarkson, T.W.; Magos, L.; Myers, G.J. The Toxicology of Mercury-Current Exposures and Clinical Manifestations. N. Engl. J. Med. 2003, 349, 1731-1737. [CrossRef]

10. Clarkson, T.W.; Magos, L. The Toxicology of Mercury and Its Chemical Compounds. Crit. Rev. Toxicol. 2006, 36, 609-662. [CrossRef]

11. Lacerda, E.M.D.C.B.; Souza, G.D.S.; Cortes, M.I.T.; Rodrigues, A.R.; Pinheiro, M.C.N.; Silveira, L.C.L.; Ventura, D.F. Comparison of Visual Functions of Two Amazonian Populations: Possible Consequences of Different Mercury Exposure. Front. Neurosci. 2019, 13, 1428. [CrossRef]

12. Grandjean, P.; White, R.F.; Nielsen, A.; Cleary, D.; de Oliveira Santos, E.C. Methylmercury Neurotoxicity in Amazonian Children Downstream from Gold Mining. Environ. Health Perspect. 1999, 107, 587-591. [CrossRef]

13. Freitas, J.S.; Lacerda, E.M.C.B.; Rodrigues Júnior, D.; Corvelo, T.C.O.; Silveira, L.C.L.; Pinheiro, M.D.C.N.; Souza, G.S. Mercury Exposure of Children Living in Amazonian Villages: Influence of Geographical Location Where They Lived during Prenatal and Postnatal Development. An. Acad. Bras. Ciências 2019, 91 (Suppl. 1). [CrossRef] [PubMed]

14. Kim, K.H.; Kabir, E.; Jahan, S.A. A Review on the Distribution of Hg in the Environment and Its Human Health Impacts. J. Hazard. Mater. 2016, 306, 376-385. [CrossRef] [PubMed]

15. Dórea, J.G.; Marques, R.C. Mercury Levels and Human Health in the Amazon Basin. Ann. Hum. Biol. 2016, 43, 349-359. [CrossRef] [PubMed]

16. Siqueira-Gay, J.; Sánchez, L.E. The Outbreak of Illegal Gold Mining in the Brazilian Amazon Boosts Deforestation. Reg. Environ. Change 2021, 21, 28. [CrossRef]

17. de Castro, N.S.S.; Lima, M.O. The Disconnection between the Brazilian Health Information System and the Cases of Mercury Exposure in Amazon. Health Inf. Manag. 2021, 50, 103-104. [CrossRef]

18. Lino, A.S.; Kasper, D.; Guida, Y.S.; Thomaz, J.R.; Malm, O. Mercury and Selenium in Fishes from the Tapajós River in the Brazilian Amazon: An Evaluation of Human Exposure. J. Trace Elem. Med. Biol. 2018, 48, 196-201. [CrossRef]

19. Guimarães, J.R.D.; Roulet, M.; Lucotte, M.; Mergler, D. Mercury Methylation along a Lake-Forest Transect in the Tapajós River Floodplain, Brazilian Amazon: Seasonal and Vertical Variations. Sci. Total Environ. 2000, 261, 91-98. [CrossRef]

20. Santos, E.C.; de Jesus, I.M.; de Magalhães, C.V.; Brabo, E.; Loureiro, E.C.; Mascarenhas, A.; Weirich, J.; Luiz, R.R.; Cleary, D. Mercury Exposure in Munduruku Indians from the Community of Sai Cinza, State of Pará, Brazil. Environ. Res. 2002, 90, 98-103. [CrossRef]

21. WHO. Environmental Health Criteria 101. In Methylmercury; World Health Organization: Geneve, Switzerland, 1990.

22. Santos Serrão de Castro, N.; de Oliveira Lima, M. Hair as a Biomarker of Long-Term Mercury Exposure in Brazilian Amazon: A Systematic Review. Int. J. Environ. Res. Public Health 2018, 15, 500. [CrossRef]

23. Berzas Nevado, J.J.; Rodríguez Martín-Doimeadios, R.C.; Guzmán Bernardo, F.J.; Jiménez Moreno, M.; Herculano, A.M.; do Nascimento, J.L.M.; Crespo-López, M.E. Mercury in the Tapajós River Basin, Brazilian Amazon: A Review. Environ. Int. 2010, 36, 593-608. [CrossRef]

24. de Oliveira Corvelo, T.C.; Oliveira, É.A.F.; de Parijós, A.M.; de Oliveira, C.S.B.; do Socorro Pompeu de Loiola, R.; de Araújo, A.A.; da Costa, C.A.; de Lima Silveira, L.C.; da Conceição Nascimento Pinheiro, M. Monitoring Mercury Exposure in Reproductive Aged Women Inhabiting the Tapajós River Basin, Amazon. Bull. Environ. Contam. Toxicol. 2014, 93, 42-46. [CrossRef] [PubMed]

25. Faial, K.; Deus, R.; Deus, S.; Neves, R.; Jesus, I.; Santos, E.; Alves, C.N.; Brasil, D. Mercury Levels Assessment in Hair of Riverside Inhabitants of the Tapajós River, Pará State, Amazon, Brazil: Fish Consumption as a Possible Route of Exposure. J. Trace Elem. Med. Biol. 2015, 30, 66-76. [CrossRef] [PubMed]

26. Malm, O.; Branches, F.; Akagi, H.; Castro, M.B.; Pfeiffer, W.; Harada, M.; Bastos, W.; Kato, H. Mercury and methylmercury in fish and human hair from the Tapajós river basin, Brazil. Sci Total Environ. 1995, 175, 141-150. [CrossRef]

27. Jesus, I.; Santos, E.; Brabo, E.; Loureiro, E.; Câmara, V.; Mascarenhas, A.; da Silva, D.; Cleary, D. Exposure to elemental mercury in urban workers and gold miners from the Tapajós Region, Pará, Brazil. Bull. Environ. Contam. Toxicol. 2001, 67, 317-323.

28. Passos, C.; Lucotte, M.; Queiroz, A.; Mergler, D.; Peleja, R.; Goch, Y. Condições sócio-econômicas e exposição ao mercúrio (Hg) através do consumo de peixe: Um estudo de caso em Santarém, Pará, Brasil. Rev. Saúde Ambiente 2003, 6, 3-11.

29. Bourdineaud, J.; Durrieu, G.; Sarrazin, S.; da Silva, W.; Mourão, R.; Oliveira, R. Mercurial exposure of residents of Santarém and Oriximiná cities (Pará, Brazil) through fish consumption. Environ. Sci. Pollut. Res. Int. 2015, 22, 12150-12161. [CrossRef] [PubMed]

30. Vieira, S.M.; de Almeida, R.; Holanda, I.B.; Mussy, M.H.; Galvão, R.C.; Crispim, P.T.; Dórea, J.G.; Bastos, W.R. Total and Methylmercury in Hair and Milk of Mothers Living in the City of Porto Velho and in Villages along the Rio Madeira, Amazon, Brazil. Int. J. Hyg. Environ. Health 2013, 216, 682-689. [CrossRef]

31. Rice, K.M.; Walker, E.M., Jr.; Wu, M.; Gillette, C.; Blough, E.R. Environmental Mercury and Its Toxic Effects. J. Prev. Med. Public Health 2014, 47, 74-83. [CrossRef] 
32. Hacon, S.; Rochedo, E.R.R.; Campos, R.R.R.; Lacerda, L.D. Mercury Exposure through Fish Consumption in the Urban Area of Alta Floresta in the Amazon Basin. J. Geochem. Explor. 1997, 58, 209-216. [CrossRef]

33. Harada, M. Congenital Minamata Disease: Intrauterine Methylmercury Poisoning. Teratology 1978, 18, 285-288. [CrossRef]

34. Counter, S.A.; Buchanan, L.H. Mercury Exposure in Children: A Review. Toxicol. Appl. Pharmacol. 2004, 198, 209-230. [CrossRef]

35. Bertossi, M.; Girolamo, F.; Errede, M.; Virgintino, D.; Elia, G.; Ambrosi, L.; Roncali, L. Effects of Methylmercury on the Microvasculature of the Developing Brain. Neurotoxicology 2004, 25, 849-857. [CrossRef] [PubMed]

36. Palheta, D.; Taylor, A. Mercury in Environmental and Biological Samples from a Gold Mining Area in the Amazon Region of Brazil. Sci. Total Environ. 1995, 168, 63-69. [CrossRef]

37. Tollefson, J. Illegal Mining in the Amazon Hits Record High amid Indigenous Protests. Nature 2021, 598, 15-16. [CrossRef] [PubMed]

38. Vasconcellos, A.C.S.D.; Hallwass, G.; Bezerra, J.G.; Aciole, A.N.S.; Meneses, H.N.M.; Lima, M.O.; Jesus, I.M.; Hacon, S.S.; Basta P.C. Health Risk Assessment of Mercury Exposure from Fish Consumption in Munduruku Indigenous Communities in the Brazilian Amazon. Int. J. Environ. Res. Public Health 2021, 18, 7940. [CrossRef] [PubMed]

39. Friedli, H.R.; Arellano, A.F.; Cinnirella, S.; Pirrone, N. Initial Estimates of Mercury Emissions to the Atmosphere from Global Biomass Burning. Environ. Sci. Technol. 2009, 43, 3507-3513. [CrossRef]

40. Michelazzo, P.A.M.; Fostier, A.H.; Magarelli, G.; Santos, J.C.; de Carvalho, J.A. Mercury Emissions from Forest Burning in Southern Amazon. Geophys. Res. Lett. 2010, 37. [CrossRef]

41. Achatz, R.W.; de Vasconcellos, A.C.S.; Pereira, L.; Viana, P.V.S.; Basta, P.C. Impacts of the Goldmining and Chronic Methylmercury Exposure on the Good-Living and Mental Health of Munduruku Native Communities in the Amazon Basin. Int. J. Environ. Res. Public Health 2021, 18, 8994. [CrossRef]

42. Perini, J.A.; Silva, M.C.; Vasconcellos, A.C.S.D.; Viana, P.V.S.; Lima, M.O.; Jesus, I.M.; Kempton, J.W.; Oliveira, R.A.A.; Hacon, S.S.; Basta, P.C. Genetic Polymorphism of Delta Aminolevulinic Acid Dehydratase (ALAD) Gene and Symptoms of Chronic Mercury Exposure in Munduruku Indigenous Children within the Brazilian Amazon. Int. J. Environ. Res. Public Health 2021, $18,8746$. [CrossRef]

43. Lee, M.R.; Lim, Y.H.; Lee, B.E.; Hong, Y.C. Blood Mercury Concentrations Are Associated with Decline in Liver Function in an Elderly Population: A Panel Study. Environ. Health 2017, 16, 17. [CrossRef]

44. Hu, X.F.; Singh, K.; Chan, H.M. Mercury exposure, blood pressure, and hypertension: A systematic review and dose-response meta-analysis. Environ. Health Perspect. 2018, 126, 076002. [CrossRef] [PubMed]

45. Malm, O. Gold Mining as a Source of Mercury Exposure in the Brazilian Amazon. Environ. Res. 1998, 77, 73-78. [CrossRef] [PubMed] 